\section{Bitterkomix 17.}

Joe Dog (Anton Kannemeyer),

Konradski (Conrad Botes) en Catherine du Toit (reds.) e.a.

Kaapstad: Isotrope \& Xlibris, 2016. 96 pp. ISBN 978-0-9922-3279-5.

DOI: http://dx.doi.org/10.17159/tvl.v.54i1.21

Die Afrikaner-Id in drukvorm, Bitterkomix, se sewentiende uitgawe het in Mei verskyn. Die voorbladskets van swart jongmense wat feesvierend skilderye en boeke verbrand, sinspeel duidelik op die vernietiging van kunswerke deur protesterende studente op die kampus van die Universiteit van Kaapstad in Februarie 2016. Bitterkomix was nog altyd 'n spreekwoordelike vreugdevuur vir tradisionele Afrikanerkultuurinhoude, maar op hierdie brandstapel sien ons juis Bitterkomix, Gif (Kannemeyer en Botes se "sekskomix" uit 1994) en 'n boek deur Hond-uitgewers. Op die eerste bladsy verklaar ' $n$ tuitbek "Captain Showerhead": "Cartoons and satire are racist! Amandla!" Soos Danie Marais (Die Burger, 4 Julie 2016) tereg opmerk, is hier vanaf die intrapslag fel kommentaar op die "moontlikheid/ onmoontlikheid van wit protes binne ons gepolariseerde postkoloniale bestel".

Die gebruiklike uitbundige anargisme word ietwat getemper omdat die uitgawe opgedra word aan Kannemeyer en Botes se vriend en mentor, die ontslape kunstenaar en uitgewer Tienie du Plessis (1949-2015) en sy dood as middelpuntsoekende krag op talle van die bydraes inwerk. Du Plessis, betrokke by die onafhanklike en dapper uitgewers Taurus en Hond, was ook saam met Gerrit Olivier aan die stuur van die "little magazine" Stet, wat in 1989 die eerste spanpoging van Kannemeyer en Botes gepubliseer het. Die selfondervraging van die omslag en stortkop-skets oor die bestaansreg en toekoms van (Afrikaanse) wit protes, word in die res van die uitgawe voortgesit deurdat daar via die stukke oor Du Plessis ook implisiet besin word oor Bitterkomix se ondergrondse wortels.

Behalwe die huldigingswoorde deur Breyten Breytenbach (86) en John Miles (87), word Du Plessis ook aandoenlik onthou in stukke soos die strip deur sy seun Daniël du Plessis ("I already live in a controlled environment, doc", 46) en sy boesemkameraad Ryk Hattingh se vertelling oor ' $n$ besoek op Du Plessis se plaas ("Vlugvoos", 76).

Voor sy sterfte was Du Plessis van plan om Michel Houellebecq se roman, Soumission (2015), in Afrikaans uit te gee. "Oorgawe" (88-91), 'n uittreksel van die eerste hoofstuk vertaal deur Catherine du Toit, word hier opgeneem as 'n pragtige wat-kon-gewees-het, met ter afsluiting 'n gepaste aanhaling van Cioran: "Werke sterf maar fragmente het nooit geleef nie en kan dus ook nie sterf nie" (91).

Du Plessis is self ook aan die woord met twee van sy gedigte (69) uit 1973, 'n artikel (vermom as onderhoud met Joe Dog) wat hy vir Bitterkomix 10 geskryf het oor Stet (78-9), asook twee strippe deur seun Daniël ("Dagskool", 80-1 en "Chitado", 84) met die tekste oor jeugdige indoktrinasie en oorlogsherinneringe deur pa Tienie uit 1991 en 2007. Van pa's en seuns gepraat: die bekende tema van 
Joe Dog se problematiese verhouding met sy vader, keer ook in hierdie uitgawe skertsend terug in Dog se "Interpretasie" (11) en "Die avonture van Tonton" (12-5).

Buiten die inhoud wat om Du Plessis wentel, is daar ook noemenswaardige bydraes soos die hoofstukke uit Joe Daly (Rust River City, 19-37) en Karlien de Villiers (My ma was 'n mooi vrou, 47-62) se grafiese romans wat beide skerp sosiopolitiese kommentaar lewer.

Hoewel hierdie uitgawe ' $n$ ernstiger inslag het as die meeste vorige Bitterkomix, is die subversiewe humor en transgressie beslis nie afgewater nie. Strippe soos "Poes" (Ryk Hattingh en Conrad Botes, 4 10) en "Tiete" (Joe Dog, 95) vra vrae oor heteroseksuele begeerte in ' $n$ polities korrekte leefwêreld. Tina Vasmaak (92-3) deel op Swiftiaanse wyse resepte met bekostigbare bronne van proteïne (vlieglarwes en semen). Kitty Skuimwyn (43-5) satiriseer die universiteitsdebatte in die vorm van ' $n$ selfhelp-rubriek met sekswerkwenke (met die nodige verwysings na Rimbaud en Bataille) vir studente wat die oudste beroep tussendeur klasloop beoefen, "[t]erwyl ons in spanning wag dat universiteite begin om programme aan te bied wat werklike relevante professionele behoeftes aanspreek en studente nie langer uitsluit deur gebruik te maak van westerse, koloniale uitvindsels soos Wiskunde nie" (43).

Soos gewoonlik kry die klassieke letterkunde ook sy plek in Bitterkomix, en in hierdie geval is dit 'n tennisbaan, waar Joe Dog se Uys en Buys-karakters met kortbroeke en rakette buiksprekers word vir'n kunsteoretiese gesprek tussen André Gide en Oscar Wilde (16-8). En dié wat sê Brecht is dood, moet Conrad Botes se treffende strip-verwerking van sy opruiende gedig "Interrogation of the Good" (38-42) beleef.

In sy vertelling oor Stet (78-9) sê Du Plessis: "[O]ns het besluit dat humor, ironie, skeppende nihilisme, gemeng met 'n skoot gesonde sinisme, die kenmerk van STET moet wees. Met ander woorde, ons wou begin kak maak in daardie stroewe tyd van onderdrukking" (78). Die ooreenkomste met Bitterkomix se aanvalsplan is ooglopend. Du Plessis sluit af: "Nou moet daar'n nuwe STET kom. Want die tyd raak ook weer ryp. Nie waar nie? Dinge is net nie meer so deursigtig as wat mens dit graag wou sien nie" (79). In hierdie dynserige tye is ondermynende kultuuruitinge nodiger as ooit-internasionaal, in Suid-Afrika, in Afrikaans-en is hierdie leser bly om te sien die transgressiewe geeste van Tienie $\mathrm{du}$ Plessis en Stet leef voort in hierdie Bitterkomix met sy Brecht en Breytenbach, sy Houellebecq en geslagsdele, sy vadermoord en vlieglarweresepte....

\section{Willem Anker}

anker@sun.ac.za

Universiteit Stellenbosch

Stellenbosch 